\title{
Strategies for Enhancing the Teaching of ICT in Business Education Programmes as Perceived by Business Education Lecturers in Universities in South South Nigeria
}

\author{
Okoro James ${ }^{1}$ \\ ${ }^{1}$ Institute of Education, Delta State University, Abraka, Nigeria \\ Correspondence: Okoro James, Institute of Education, Delta State University, Abraka, Nigeria. E-mail: \\ jimkorokpeu@yahoo.com
}

Received: August 5, 2013

Accepted: September 16, $2013 \quad$ Online Published: September 28, 2013

doi:10.5539/ies.v6n10p78

URL: http://dx.doi.org/10.5539/ies.v6n10p78

\begin{abstract}
This study assessed the strategies for enhancing the teaching of ICT in Business Education programme as perceived by Business Education lecturers in universities in south south Nigeria. Three research questions and six hypotheses guided the study. The design of this study was a descriptive survey. The population which also served as a sample comprised 134 Business Education lecturers in universities in the south south geopolitical zone of Nigeria. The instrument for data collection was a 66 - item questionnaire. The instrument was validated by experts in Business Education. The internal consistency of the instrument was determined using cronbach alpha, which has a reliability coefficient of 0.93 . The data were analysed using mean and standard deviation. The study revealed the prospects of teaching ICT: ICT facilitates interaction between lecturers and students; ICT enhances effective storage of business information; ICT facilitates the retrieval of business information. The study also revealed constraints facing the teaching of ICT such as inadequate ICT facilities/equipment; frequent electricity interruption of ICT facilities and poor implementation of ICT policies. Moreover, the study revealed some strategies for enhancing the teaching of ICT: adequate funding of ICT facilities; provision of adequate ICT equipment; provision of adequate ICT facilities among others. Among the recommendations made were that Business Education lecturers should undergo training and retraining in ICT programme to have more skills and competencies, that adequate ICT facilities should be provided by university authorities to enable lecturers carry out their teaching assignment effectively.
\end{abstract}

Keywords: strategies, teaching, information and communication technology, business education, universities in Nigeria

\section{Introduction}

Business Education is education for and about business or training in business skills (Esene, 2012). Business Education according to Okoli (2010) is that aspect of the total educational programme that provides the knowledge, skills, understanding and attitudes needed to perform effectively in the business world as a producer and/or consumer of goods and services that business offers. Business Education is an important part of general education which emphasises skill acquisition for office use. Business Education is a programme of instruction that consists of two parts, namely office education - a programme of vocation for office careers, and general Business Education - a programme which provides the recipients with competencies and skills needed in managing personal business affairs and using the services of the business world (Ezenwafor, 2012). An individual who receives training in Business Education can easily develop potentials for entrepreneurship pursuits especially in this era of economic melt down and unemployment (Ibeneme \& Ikegwuani, 2010). Business Education which is offered at the universities and colleges of education is concerned mainly with the development of relevant and saleable skills and knowledge that would enable an individual to function effectively in the world of work (Onojetah, 2012). Business Education programme, according to the American Vocational Association (AVA, 1980), is a broad and comprehensive discipline whose instructional programme encompasses knowledge, skills, vocation and aptitude needed by all citizens in order to effectively manage their personal businesses and also function in the economic system. 
Business Education provides employment for graduates. In Business Education programme, courses in marketing, management, accounting and office technology and management are offered by the students. Business Education students are expected to possess the relevant skills, competencies and knowledge in these major aspects of Business Education graduation. The objectives of introducing Business Education at university level are:

1) to produce competent degree graduates who can be self-employed;

2) to produce competent degree graduates who can teach Business Education courses in secondary school and higher institutions;

3) to produce competent degree graduates who can inculcate business ideas into the economy;

4) to produce competent degree graduates who can help in formulating economic policies;

5) to produce competent degree graduates who can employ other persons to reduce unemployment.

In order to make Business Education graduates more relevant in the Nigerian economy and the world over in terms of job creation, information and communication technology has been introduced into the Business Education curriculum. This is necessitated by the fact that the world is viewed as a 'global village' due to the technological advancement in the communication skills and gadgets.

Due to globalisation, the computer has become a very important tool in almost every work place, economy, education system, and in the lives of individuals. In recognition of this necessity, the Federal Republic of Nigeria (FRN) in 1998 set up the National Committee on Computer Education to determine the modes of integrating computer education into the nation's education system (Okigbo \& Okeke, 2012). The committee later established a policy in computer education which states that Nigerians at various levels of education should be brought into contact with this modern tool, so that they can use it, appreciate its potentials, understand how it works, and learn how to apply it to solve every day problems (Agbatogun, 2006).

The objectives of computer education according to FRN (2004) are to:

- Bring about a computer literate society in Nigeria within a short span of time;

- Enable the school children at all levels to appreciate the potentials of the computer;

- Enable them to use computer in their various works of life and later education.

The emergence of Information and Communication Technology (ICT) as recorded in recent times has brought advancement in different spheres of human endeavour; education, business and so on. So many technological tools, gadgets and software programmes are being discovered on daily basis and the need to develop our human capital towards the acquisition and utilisation of these knowledge becomes inevitable (Okoli, 2012). Education is regarded as the bedrock of any national development and the issue of technological application in teaching and learning is considered a priority for other resource areas to tap into. Igberaharha (2009) notes that education in Nigeria, in this rapidly changing and competitive environment, cannot be relevant without effective preparation of the new generation (both teachers and students) to make effective use of the new information and communication technology in their professional practices.

Information and communication technology is a system that is used in the processing, storage and transfer of information which can be audio, visual or both in the form of numbers, letters and pictures. The application of ICT in teaching and learning has raised considerable concern among individuals and the government who made it emphatically clears in its NEEDS- 2 programme that Nigeria should not be caught in the web of ignorance as other nations anchor their development programmes and plans on the technologies such as ICT (National Planning Commission, 2004). To this effect, efforts were made by the federal government of Nigeria at different times to promote the provision and utilisation of ICT equipment in educational institutions, especially in the universities which are regarded as the highest level of education (Okoli, 2012).

Information and Communication Technology as applied to Business Education according to Igberaharha (2009) involves the use of networks, expert systems, and artificial intelligence in what is now known as electronic commerce (e-commerce) or electronic business (e-communication business). E-commerce helps to facilitate the exchange of information, goods and services between companies and their customers. Business operations are also much dependent on ICT. This is because the impact of communication and information technology is felt in all aspects of an organisation's life from manufacturing to the service sector particularly marketing. Igberaharha (2009) opines that information technology affects the entire marketing strategy framework and covers relationships with suppliers and manufacturers, the internal organization of the firm and the firm's interaction with its customers. It helps marketers to work with customers in more efficient ways like linking purchases with 
specific customers. In the school system especially at university level, there are some prospects that could be derived in teaching ICT. Prospects mean advantages or benefits that could be derived for using a particular object (Ukor, 2009). Inije (2012) notes the following prospects of teaching ICT in Business Education: ICT facilitates information exchange amongst members of the business community and between them and the outside word; it facilitates interaction between lecturers and students; it enhances effective storage and retrieval of information and it makes information easily accessible at a very fast rate thereby enabling pre-serve Business Education teachers to acquire necessary concepts without barrier.

The aforementioned uses of information and communication technology in business management help in creating higher profits and opportunities for business expansion and economic growth. Unfortunately, the adoption of e-learning in Nigerian universities has remained a mirage due to its slow pace of acceptance and use (Manir, 2009; Bassey, Uworen, Akuegwu, Udida and Ntukidem, 2007). Little knowledge of ICT usage is observed among business teachers, as their students prove naive of e-learning practices in their trainings (Ngurukwem, 2005). This has been attributed to such factors as inadequate fund available to schools for training of their teachers in ICT skill acquisition, high cost of ICT equipment and electronic devices and constant electric power failure (Aduwa- Agiegbaen and lyamu, 2005; Ohakwe and Njoku, 2010). Okoli (2010) also identifies the following constraints of teaching ICT: inadequate equipment and infrastructure, scarcity of curriculum developers, inadequate personnel, inadequate textbooks and other teaching materials and the impediments in the power sector. In the same vein, Onojetah (2012) identifies some constraints of teaching ICT in Business Education, inadequate infrastructure, inadequate funding, acute manpower shortage, lack of access to utilise ICT resources at will and non-availability of computer laboratories. This unsatisfactory manner of practice in the delivery of business programmes in line with technological innovations has created a vacuum in the attainment of the national technology objectives and non-performance of the graduates in the business world.

The problems facing the teaching of ICT can easily be addressed with some strategies. Yomere and Esosa (2011) define strategy of a firm as "a well-considered pattern of resources deployment that is appropriate and adequate for achieving the desired quality and level of effective interaction with the environment". In effect, a strategy is a means to an end. It is the mechanism by which an organization deploys its resources - men, material, machines, financial - to execute a plan of action that has been laid out to achieve an objective efficiently and effectively. Ugwuanyi and Eze (2009) identify the strategies for enhancing the teaching of ICT in Business Education as availability of adequate computers on the basis of one student to one computer during class sessions, provision of reprographic machines such as photocopiers and duplicators, micrographics such as microfilming machines, electronic communication equipment such as e-mail, facsimile (FAX), telex machines, word processing laboratories fitted with air conditioners and good lighting, office practice laboratories equipped with modern office equipment, audio visuals, chalkless boards and stand-by generating sets. Ejiofor and Osinem (2010) also suggest some strategies for enhancing the teaching of ICT in Nigerian universities:

- students and teachers must have sufficient access to digital technologies and internet in their classrooms, schools and teacher education institutions;

- $\quad$ high quality, meaningful, and culturally responsive digital content must be available for teachers and learners;

- teachers must have the knowledge and skills to use the new digital tools and resources to help all students achieve high academic standards;

Egboka (2012) notes these strategies for enhancing the teaching of ICT,

- the management of universities should build stronger links with multinational businesses and other external stakeholders to assist them in providing ICT facilities in their universities;

- the universities' portals should be used to disseminate updated university policy statements to staff, students and interested public;

- the management of the universities should develop legal and policy frameworks that stipulate their rationale for ICT empowerment in their institutions;

\section{Theoretical Framework}

Besides the theory of operant conditioning by B. F. Skinner that supports the control of the learning environment with reinforcing stimuli (ICT tools) to strengthen behaviour; there are other theories that justify the investigation into strategies for enhancing the teaching of ICT among the business teachers to achieve success in the teaching of ICT in universities (Okoli, 2012). 
First is the activity theory that describes an activity system. The use of tools in human activity is seen as 'mediated' higher functioning in interaction between a subject (an individual) and an object (a task), (Okoli, 2012). The tool with which a teacher interacts within the learning environment depends on his objectives in the activity system that shapes the interpretation, relevance and the meaning of the meditational tool. This presupposes that the concept of ICT use in the learning environment is a matter of cognition in its relevance; precisely referring to the ability of the user: the teacher and the learner alike to achieve effectiveness and the institutional activities necessary in its provision and support to the users to make it less problematic.

The issue of how to produce knowledgeable and skilled business graduates who can perform effectively in the teaching of ICT in the various business fields of the global economy has motivated this study among business teachers in Nigerian universities. Theoretical teaching of ICT should be discouraged and students should be guided to discover things for themselves with the teacher acting as a mediator in learning. It is paramount that effort should geared towards achieving maximum results by using up-to-date technologies in the teaching of ICT among business educators.

\section{Statement of the Problem}

Research findings by Nwaiwu (2009) reveals that Business Education students perform poorly in ICT courses and most Business Education graduates are not competent in ICT skills. This can negatively affect entrepreneurial ventures since they lack ICT skills to run businesses successfully. Onojetah (2012) reveals debilitating factors such as inadequate funding of ICT by government and school authorities, poor maintenance culture of ICT facilities, use of obsolete computers and prior method of content delivery. The teaching of ICT is theoretical rather than practical in most universities in Nigeria. Egboka (2012) also reveals that lecturers are not provided with ICT trainers to guide them in supervised practice until they are comfortable with using ICT on their own, lecturers are not provided with ICT educational resources that are directly related to the curriculum and assessment methods used to evaluate education outcomes and that the universities have not made their lecturers aware of the rationale for teaching ICT. The poor condition of teaching ICT in Nigeria universities cannot help the graduates to possess the requisite skills that will enable perform effectively in their entrepreneurial ambitions. The problem of the study therefore, is: what are the strategies for enhancing the teaching of information and communication technology in Business Education in Nigerian universities?

\section{Purpose of the Study}

The purpose of the study is to assess the strategies for enhancing the teaching of ICT in Business Education programme in universities in the south south geopolitical zone of Nigeria. Specifically, the objectives are

1) To identify the prospects of teaching ICT in Business Education programme;

2) To identify the constraints facing the teaching of ICT in Business Education programme;

3) To identify the strategies for enhancing the teaching of ICT in Business Education programme;

\section{Research Questions}

The following research questions are raised to guide the study.

1) What are the prospects of teaching ICT in Business Education programme?

2) What are the constraints facing the teaching of ICT in Business Education programme?

3) What are the strategies for enhancing the teaching of ICT in Business Education programme?

\section{Hypotheses}

The following hypotheses were tested at 0.05 level of significance

1) There is no significant difference between male and female Business Education lecturers' mean rating of prospects of teaching ICT in Business Education programme.

2) There is no significant difference between male and female Business Education lecturers' mean rating of constraints facing the teaching of ICT in Business Education programme.

3) There is no significant difference between male and female Business Education lecturers' mean rating of strategies for enhancing the teaching of ICT in Business Education programme.

4) There is no significant difference between state and federal universities Business Education lecturers' mean rating of prospects of teaching ICT in Business Education programme.

5) There is no significant difference between state and federal universities Business Education lecturers' mean rating of constraints facing the teaching of ICT in Business Education programme. 
6) There is no significant difference between state and federal universities Business Education lecturers' mean rating of strategies for enhancing the teaching of ICT in Business Education programme.

\section{Method}

This study adopted a descriptive survey design. A descriptive survey design was used for this study because it is aimed at ascertaining and establishing the status quo, facts or pieces of information concerning the population. According to Esene (2009), survey method is appropriate, especially for seeking individuals' opinions, attitudes and perceptions in their natural setting. The population of the study comprised 134 Business Education lecturers in state and federal universities in the south south geopolitical zone of Nigeria. There was no sampling since the population in the zone was manageable. The instrument for data collection was a 66 - item questionnaire. It had two sections. Section A of the questionnaire had 3 items on demographic variables of the respondents (sex, university type, teaching experience). Section B had 63 items based on the research questions. The questionnaire had a four point scale of Strongly Agree (SA), Agree (A), Disagree (D) and Strongly Disagree (SD). The content and face validity of the instrument was carried out by three experts in Business Education and two experts in Measurement and Evaluation. The instrument was also validated using factor analysis. In order to carry out the reliability of the instrument, the questionnaire was administered to 35 Business Education lecturers in South East universities of Nigeria which was not part of the study. The data collected were analysed and the internal consistency of the instrument was determined using cronbach alpha, which has a reliability coefficient of 0.93 . The data were analysed using mean and standard deviation to answer the researcher questions. In analysing the data, the response options in the questionnaire were weighted as follows: Strongly Agree - 4points, Agree 3 points, Disagree - 2points, Strongly Disagree - 1point. A cut-off point of 2.50 was set to agree or disagree items on the instrument. Mean score above 2.50 showed agreed, while mean score less than 2.50 showed disagreed. Z-test statistics was used to test the hypotheses at 0.05 level of significance. If the calculated value $(\mathrm{CV})$ is less than table value (tv) 1.96 , the hypothesis is retained. On the other hand, if z-calculated (zc) is above table value (tv), the hypothesis is rejected.

\section{Results}

The result of the study are presented and analysed in the following table.

Research questions one: What are the prospects of teaching ICT in Business Education programme?

Table 1. Mean ratings and SD of the respondents on assessment of prospects of teaching ICT in Business Education programme. $(\mathrm{N}=134)$

\begin{tabular}{|c|c|c|c|c|}
\hline $\mathbf{S} / \mathbf{N}$ & Prospects of teaching of ICT in Business Education & Mean & SD & Remark \\
\hline 1 & $\begin{array}{l}\text { ICT helps in facilitating information exchange among the Business } \\
\text { Education lecturers }\end{array}$ & 2.71 & 0.94 & Agreed \\
\hline 2 & ICT facilitates interaction between lecturers and students & 2.80 & 0.89 & Agreed \\
\hline 3 & ICT enhances effective storage of business information & 2.79 & 0.91 & Agreed \\
\hline 4 & ICT facilitates in the retrieval of business information & 2.89 & 0.78 & Agreed \\
\hline 5 & $\begin{array}{l}\text { ICT facilitates pre-service Business Education lecturers to acquire } \\
\text { necessary concepts without barriers }\end{array}$ & 2.54 & 0.89 & Agreed \\
\hline 6 & $\begin{array}{l}\text { ICT emphasises important aspects of learning thereby discouraging } \\
\text { rote learning among students }\end{array}$ & 2.69 & 0.90 & Agreed \\
\hline 7 & $\begin{array}{l}\text { ICT provides connected and distributed network among lecturers } \\
\text { and students }\end{array}$ & 2.80 & 0.78 & Agreed \\
\hline 8 & ICT enhances retention of learning among students & 2.74 & 0.68 & Agreed \\
\hline 9 & $\begin{array}{l}\text { ICT enhances individualised Business Education instruction } \\
\text { packages readily available to students }\end{array}$ & 2.69 & 0.87 & Agreed \\
\hline 10 & $\begin{array}{l}\text { ICT improves both efficiency and effectiveness of Business } \\
\text { Education lecturers }\end{array}$ & 2.98 & 0.82 & Agreed \\
\hline 11 & ICT enhances physical involvement of the learners & 2.90 & 0.78 & Agreed \\
\hline 12 & ICT aids in evaluation and appraisal of students & 2.85 & 0.72 & Agreed \\
\hline 13 & ICT facilitates learning content requiring repetition & 2.67 & 0.76 & Agreed \\
\hline 14 & $\begin{array}{l}\text { ICT assists lecturers and students to demonstrate experiments and } \\
\text { concepts }\end{array}$ & 2.52 & 0.94 & Agreed \\
\hline 15 & ICT makes pre-service Business Education teachers to learn faster & 2.60 & 0.87 & Agreed \\
\hline
\end{tabular}


and perform better

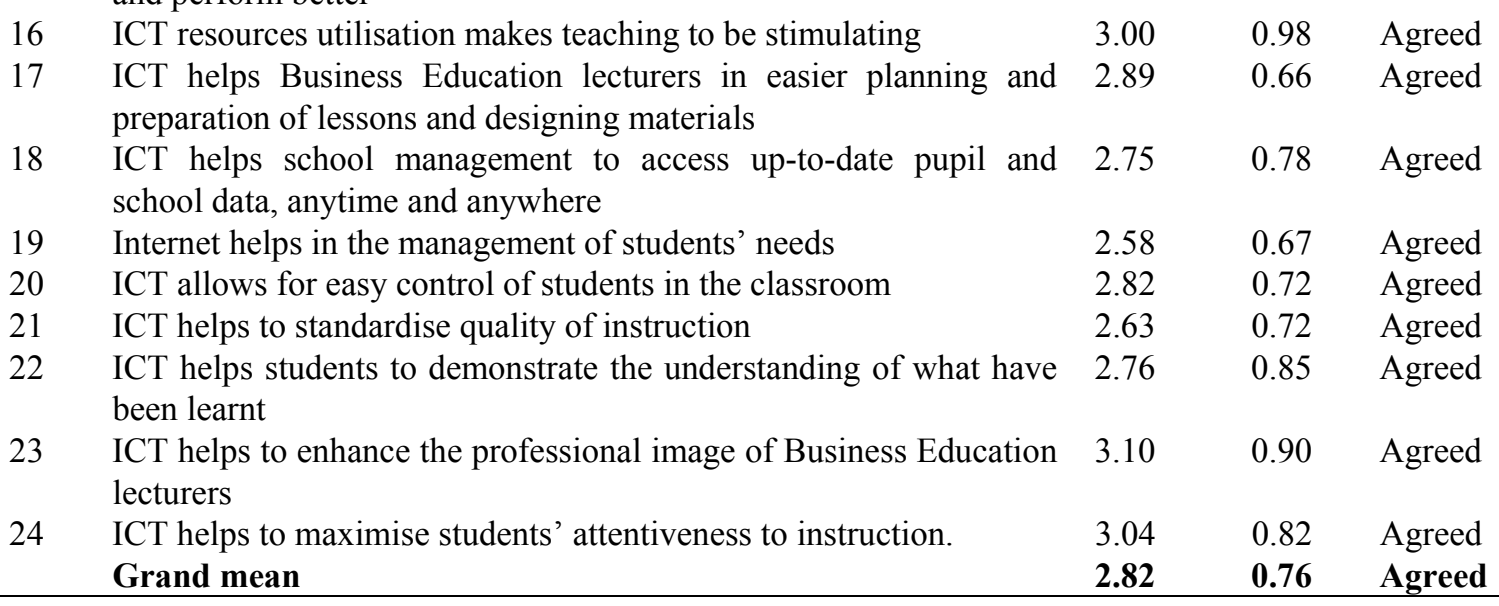

Table 1 contains twenty four (24) items on prospects of teaching ICT in Business Education. ICT helps to enhance the professional image of Business Education lecturers recorded 3.10 followed by ICT helps to maximise students' attentiveness which was 3.04, while ICT assists lecturers and students to demonstrate experiments and concepts has the lowest mean of 2.52. The data show that all items are prospects of teaching ICT in Business Education.

Table 2. Mean ratings and SD of the respondents on assessment of constraints facing the teaching of ICT in Business Education programme. $(\mathrm{N}=134)$

\begin{tabular}{lllll}
\hline S/N & Constraints facing the teaching of ICT in Business Education & Mean & SD & Remark \\
\hline 25 & Inadequate ICT equipment in Business Education & 2.80 & 0.91 & Agreed \\
26 & Inadequate ICT facilities in business education & 2.72 & 0.71 & Agreed \\
27 & Frequent electricity interruption of ICT facilities in Business & 2.90 & 0.89 & Agreed \\
& Education & & & \\
28 & Poor implementation of ICT policies in Business Education & 2.89 & 0.70 & Agreed \\
29 & Inadequate qualified ICT personnel in Business Education & 2.97 & 0.89 & Agreed \\
30 & High cost of ICT facilities in Business Education & 2.99 & 0.75 & Agreed \\
31 & High cost of ICT components in Business Education & 2.82 & 0.69 & Agreed \\
32 & Inadequate funding of ICT facilities in Business Education & 2.81 & 0.74 & Agreed \\
33 & Limited ICT skills among lecturers in Business Education & 2.90 & 0.98 & Agreed \\
34 & Obsolete computers being used in teaching ICT in Business & 2.58 & 0.89 & Agreed \\
& Education & & & \\
35 & Poor overcrowded classrooms & 2.73 & 0.70 & Agreed \\
36 & Poor ICT maintenance culture in Business Education & 2.88 & 0.96 & Agreed \\
37 & Lack of interest to use ICT facilities by the lecturers in Business & 2.95 & 0.83 & Agreed \\
& Education & & & \\
38 & Lack of interest to use ICT facilities by the students & 2.79 & 0.94 & Agreed \\
39 & Low level of ICT connectivity in Business Education & 2.87 & 0.74 & Agreed \\
40 & ICT facilities in Business Education are a target for vandals and & 2.86 & 0.61 & Agreed \\
& burglars. & & & \\
41 & Inadequate use of ICT textbooks in Business Education & 2.70 & 0.80 & Agreed \\
42 & Poor method of teaching ICT in Business Education & 3.15 & 0.71 & Agreed \\
43 & Lack of ICT curriculum experts in Business Education & 2.79 & 0.69 & Agreed \\
44 & Government nonchalant attitude towards ICT policy & 2.60 & 0.73 & Agreed \\
& Grand mean & $\mathbf{2 . 7 9}$ & $\mathbf{0 . 8 0}$ & Agreed \\
\hline
\end{tabular}

Table 2 contains twenty (20) items on constraints facing the teaching of ICT in Business Education. Poor method of teaching ICT has highest mean score of 3.15 followed by high cost of ICT facilities which has a mean score of 
2.99, while Obsolete computers being used in teaching ICT has the lowest mean score of 2.58. The data show that all the above is constraints facing the teaching of ICT in Business Education.

Table 3. Mean ratings and SD of the respondents on assessment of strategies for enhancing the teaching of ICT in Business Education programme. $(\mathrm{N}=134)$

\begin{tabular}{|c|c|c|c|c|}
\hline $\mathbf{S} / \mathbf{N}$ & Strategies for enhancing the teaching of ICT in Business Education & Mean & SD & Remark \\
\hline 45 & $\begin{array}{l}\text { Adequate funding of ICT facilities by school authorities can enhance } \\
\text { the teaching of ICT in Business Education }\end{array}$ & 2.71 & 0.87 & Agreed \\
\hline 46 & $\begin{array}{l}\text { Provision of adequate ICT equipment by school authorities can enhance } \\
\text { the teaching of ICT in Business Education }\end{array}$ & 2.89 & 0.90 & Agreed \\
\hline 47 & $\begin{array}{l}\text { Provision of adequate ICT facilities by school authorities can enhance } \\
\text { the teaching of ICT in Business Education }\end{array}$ & 2.90 & 0.81 & Agreed \\
\hline 48 & $\begin{array}{l}\text { Provision of adequate electricity supply by school authorities can } \\
\text { enhance the teaching of ICT in business education }\end{array}$ & 3.10 & 0.70 & Agreed \\
\hline 49 & $\begin{array}{l}\text { Proper implementation of ICT policies by school authorities can } \\
\text { enhance the teaching of ICT in Business Education }\end{array}$ & 2.88 & 0.69 & Agreed \\
\hline 50 & $\begin{array}{l}\text { Employment of adequate qualified ICT teachers by school authorities } \\
\text { can enhance the teaching of ICT in Business Education }\end{array}$ & 2.89 & 0.95 & Agreed \\
\hline 51 & $\begin{array}{l}\text { Reduction in cost of ICT facilities by suppliers can enhance the } \\
\text { teaching of ICT in Business Education }\end{array}$ & 2.97 & 0.68 & Agreed \\
\hline 52 & $\begin{array}{l}\text { Reduction in cost of ICT equipment can enhance the teaching of ICT in } \\
\text { Business Education }\end{array}$ & 2.79 & 0.86 & Agreed \\
\hline 53 & $\begin{array}{l}\text { Sponsoring of lecturers to attend workshops/seminars can enhance the } \\
\text { teaching of ICT in Business Education }\end{array}$ & 2.75 & 0.76 & Agreed \\
\hline 54 & $\begin{array}{l}\text { Purchasing of modern computers by school authorities can enhance the } \\
\text { teaching of ICT in Business Education }\end{array}$ & 2.80 & 0.90 & Agreed \\
\hline 55 & Provision of adequate lecture halls & 2.83 & 0.91 & Agreed \\
\hline 56 & $\begin{array}{l}\text { Good management policies on ICT by school authorities can enhance } \\
\text { the teaching of ICT in Business Education }\end{array}$ & 2.79 & 0.87 & Agreed \\
\hline 57 & $\begin{array}{l}\text { Good maintenance culture of ICT by school authorities can enhance the } \\
\text { teaching of ICT in business education }\end{array}$ & 2.76 & 0.86 & Agreed \\
\hline 58 & $\begin{array}{l}\text { Lecturers' positive attitude on the relevance of ICT can enhance the } \\
\text { teaching of ICT in Business Education }\end{array}$ & 2.99 & 0.78 & Agreed \\
\hline 59 & $\begin{array}{l}\text { Students positive attitude on the relevance of ICT can enhance the } \\
\text { teaching of ICT in Business Education }\end{array}$ & 3.00 & 0.70 & Agreed \\
\hline 60 & $\begin{array}{l}\text { Provision of adequate equipped offices for lecturers in Business } \\
\text { Education }\end{array}$ & 2.66 & 0.83 & Agreed \\
\hline 61 & $\begin{array}{l}\text { Provision of adequate computers on the basis of one student to one } \\
\text { computer during class sessions }\end{array}$ & 2.79 & 0.68 & Agreed \\
\hline 62 & $\begin{array}{l}\text { Provision of adequate word processing laboratories fitted with air } \\
\text { conditioners and good lighting by school authorities can enhance the } \\
\text { teaching of ICT in Business Education }\end{array}$ & 2.60 & 0.99 & Agreed \\
\hline \multirow[t]{2}{*}{63} & $\begin{array}{l}\text { Provision of reprographic machines such as copiers and duplicators by } \\
\text { school authorities can enhance the teaching of ICT in Business } \\
\text { Education }\end{array}$ & 2.72 & 0.84 & Agreed \\
\hline & Grand mean & 2.81 & 0.72 & Agreed \\
\hline
\end{tabular}

Table 3 contains seventeenth (17) items on strategies for enhancing the teaching of ICT in Business Education Provision of adequate electricity supply by school authorities has a mean score of 3.10 followed by Students positive attitude on the relevance of ICT which has mean score of 3.00, while Provision of adequate word processing laboratories fitted with air conditioners and good lighting by school authorities has the lowest mean score of 2.60. The data shows that all the above are strategies for enhancing the teaching of ICT in Business Education. 


\section{Hypothesis 1}

There is no significant difference between male and female Business Education lecturers' mean rating of prospects of teaching ICT in Business Education programme.

Table 4. Z-test result of the difference in respondents' mean rating of prospect of teaching ICT in Business Education based on gender

\begin{tabular}{llllllll}
\hline Variables & $\mathbf{N}$ & Mean & SD & Df & Z-cal & Z-tab & Remarks \\
\hline Male & 79 & 38.77 & 11.30 & & & & \\
Female & 55 & 36.72 & 10.72 & & 0.974 & 1.960 & NS \\
\hline
\end{tabular}

In the table, the calculated $z$-value of 0.974 is less than the z-tabulated value of 1.960 at 132 degree of freedom at 0.05 level of significance. This means that there was no significant difference in the mean rating of male and female respondents on assessment of prospects of teaching ICT in Business Education programme. The null hypothesis is, therefore, upheld while the alternate hypothesis is rejected.

\section{Hypothesis 2}

There is no significant difference between male and female Business Education lecturers' mean rating of constraints facing the teaching of ICT in Business Education programme.

Table 5. Z-test result of the difference in respondents' mean rating of constraints facing the teaching of ICT in Business Education based on gender

\begin{tabular}{llllllll}
\hline Variables & $\mathbf{N}$ & Mean & SD & Df & Z-cal & Z-tab & Remarks \\
\hline Male & 79 & 37.61 & 10.22 & & & & \multirow{2}{*}{132} \\
Female & 55 & 35.06 & 11.34 & & 1.08 & 1.960 & NS \\
\hline
\end{tabular}

In the table, the calculated z-value of 1.08 is less than the z-tabulated value of 1.960 at 132 degree of freedom at 0.05 level of significance. This means that there was no significant difference in the mean rating of male and female respondents on assessment of constraints facing the teaching of ICT in Business Education programme. The null hypothesis, is, therefore, upheld while the alternate hypothesis is rejected.

\section{Hypothesis 3}

There is no significant difference between male and female Business Education lecturers' mean rating of strategies for enhancing the teaching of ICT in Business Education programme.

Table 6. Z-test result of the difference in respondents' mean rating of strategies for enhancing the teaching of ICT in Business Education based on gender

\begin{tabular}{llllllll}
\hline Variables & N & Mean & SD & Df & Z-cal & Z-tab & Remarks \\
\hline Male & 79 & 36.04 & 13.01 & & & & \\
& & & & 132 & 0.914 & 1.960 & NS \\
Female & 55 & 34.12 & 13.77 & & & & \\
\hline
\end{tabular}

In the table, the calculated $z$-value of 0.914 is less than the z-tabulated value of 1.960 at 134 degree of freedom at 0.05 level of significance. This means that there was no significant difference in the mean rating of male and female respondents on assessment of strategies for enhancing the teaching of ICT in Business Education programme. The null hypothesis, is, therefore upheld while the alternate hypothesis is rejected.

\section{Hypothesis 4}

There is no significant difference between state and federal universities Business Education lecturers mean rating of prospects of teaching ICT in Business Education programme. 
Table 7. Z-test result of the difference in respondents' mean rating of prospects of teaching ICT in Business Education based on university type

\begin{tabular}{llllllll}
\hline Variables & N & Mean & SD & Df & Z-cal & Z-tab & Remarks \\
\hline State universities lecturers & 81 & 36.44 & 11.66 & & \multirow{2}{*}{1.14} & 1.960 & NS \\
& 53 & 34.72 & 10.41 & & & & \\
Federal universities lecturer & 53 & & & & &
\end{tabular}

In the table, the calculated z-value of 1.14 is less than the z-tabulated value of 1.960 at 132 degree of freedom at 0.05 level of significance. This means that there was no significant difference in the mean rating of state and federal universities respondents on assessment of prospects of teaching ICT in Business Education programme. The null hypothesis, is, therefore, upheld while the alternate hypothesis is rejected.

\section{Hypothesis 5}

There is no significant difference between state and federal universities Business Education lecturers' mean rating of constraints facing the teaching of ICT in Business Education programme.

Table 8. Z-test result of the difference in respondents' mean rating of constraints facing the teaching of ICT in Business Education based on university type

\begin{tabular}{llllllll}
\hline Variables & N & Mean & SD & Df & Z-cal & Z-tab & Remarks \\
\hline $\begin{array}{l}\text { State } \\
\text { universities }\end{array}$ & 81 & 39.66 & 13.58 & & & & \\
lecturers & & & & & & & \\
$\begin{array}{l}\text { Federal } \\
\text { universities } \\
\text { lecturers }\end{array}$ & 53 & 37.12 & 13.01 & & 0.928 & 1.960 & NS \\
\hline
\end{tabular}

In the table, the calculated z-value of 0.928 is less than the z-tabulated value of 1.960 at 132 degree of freedom at 0.05 level of significance. This means that there was no significant difference in the mean rating of state and federal universities respondents on assessment of constraints facing the teaching of ICT in Business Education programme. The null hypothesis, is, therefore, upheld while the alternate hypothesis is rejected.

\section{Hypothesis 6}

There is no significant difference between state and federal universities Business Education lecturers' mean rating of strategies for enhancing the teaching ICT in Business Education programme.

Table 9. Z-test result of the difference in respondents' mean rating of strategies for enhancing the teaching of ICT in Business Education based on university type

\begin{tabular}{llllllll}
\hline Variables & N & Mean & SD & Df & Z-cal & Z-tab & Remarks \\
\hline $\begin{array}{l}\text { State } \\
\text { universities } \\
\text { lecturers }\end{array}$ & 81 & 39.15 & 14.06 & & & & \\
& & & 132 & 0.993 & 1.960 & NS \\
$\begin{array}{l}\text { Federal } \\
\begin{array}{l}\text { universities } \\
\text { lecturers }\end{array}\end{array}$ & 53 & 38.52 & 12.94 & & & & \\
\hline
\end{tabular}

In the table, the calculated z-value of 0.993 is less than the z-tabulated value of 1.960 at 132 degree of freedom and 0.05 level of significance. This means that there was no significant difference in the mean rating of state and 
federal universities respondents on assessment of strategies for improving the use of ICT in Business Education programme. The null hypothesis, is, therefore, upheld, while the alternate hypothesis is rejected.

\section{Discussion of Findings}

The study revealed that the following are prospects of teaching ICT, namely ICT helps in facilitating information exchange among the Business Education lecturers; ICT facilitates interaction between lecturers and students; ICT enhances effective storage of business information; ICT facilitates in the retrieval of business information; ICT facilitates pre-service Business Education lecturers to acquire necessary concepts without barriers; ICT emphasises important aspects of learning thereby discouraging rote learning among students; ICT provides connected and distributed network among lecturers and students; ICT enhances retention of learning among students; ICT enhances individualised Business Education instruction packages readily available to students; ICT improves both efficiency and effectiveness of Business Education lecturers; ICT enhances physical involvement of the learners; ICT aids in evaluation and appraisal of students; ICT facilitates learning content requiring repetition; ICT assists lecturers and students to demonstrate experiments and concepts; ICT makes pre-service Business Education teachers to learn faster and perform better; ICT resources utilisation makes teaching to be stimulating; ICT helps Business Education lecturers in easier planning and preparation of lessons and designing materials; ICT helps school management to access up-to-date pupil and school data; anytime and anywhere, Internet helps in the management of students' needs; ICT allows for easy control of students in the classroom; ICT helps to standardise for quality of instruction; ICT helps students to demonstrate the understanding of what have been learnt; ICT helps to enhance the professional image of Business Education lecturers and ICT helps to maximise students attentiveness to instruction. This study supports the study of Igberaharha (2009), Inije (2012) and Okoli (2012) who have identified the prospects of teaching ICT which include effective interaction with students and lecturers; ICT facilitates storage, processing and retrieval of information; active participation by students among others. The result of hypotheses revealed that there was no significant difference between male and female Business Education lecturers' mean rating of prospects of teaching ICT in Business Education programme, there was no significant difference between state and federal universities Business Education lecturers' mean rating of prospects of teaching ICT in Business Education programme.

The study revealed that the following are constraints facing the teaching of ICT, namely inadequate ICT equipment in Business Education, inadequate ICT facilities in business education, frequent electricity interruption of ICT facilities in Business Education, poor implementation of ICT policies in Business Education, Inadequate qualified ICT personnel in Business Education, high cost of ICT facilities in Business Education, high cost of ICT components in business education, inadequate funding of ICT facilities in Business Education, limited of ICT skills among lecturers in Business Education, obsolete computers being used in the teaching of ICT in Business Education, poor management on the parts of school administration, poor ICT maintenance culture in Business Education, lack of interest to use ICT facilities by the lecturers in Business Education, lack of interest to use ICT facilities by the students, lack of ICT slow connectivity in business education, ICT facilities area target for vandals and burglars, inadequate use of ICT textbooks in business education, Lack of ICT curriculum experts in Business Education and Government's nonchalant attitude towards ICT policy. This study supports the earlier study of Aduwa-Agiegbaen and Iyamu, 2005; Ohakwe and Njoku, 2010), Okoli (2010) who have identified similar constraints facing the teaching of ICT in Business Education such as inadequate ICT facilities/equipment, inadequate funding, inadequate qualified teaching personnel among others. The result of the hypotheses also revealed that there was no significant difference between male and female Business Education lecturers' mean rating of constraints facing the teaching of ICT in Business Education programme, there was no significant difference between state and federal universities Business Education lecturers mean rating of constraints facing the teaching of ICT in Business Education programme

The findings also revealed that the following are strategies for enhancing the teaching of ICT, namely adequate funding of ICT facilities, provision of adequate ICT equipment by school authorities, provision of adequate ICT facilities, provision of adequate electricity supply, proper implementation of ICT policies, employment of adequate qualified ICT teachers, reduction in cost of ICT facilities, reduction in cost of ICT equipment, sponsoring of lecturers to attend workshops/seminars, Purchasing of modern computers by school authorities, good management policies on ICT by school authorities, good maintenance culture of ICT by school authorities, lecturers positive attitude on the relevance of ICT, students' positive attitude on the relevance of ICT, provision of adequate office practice laboratory equipment, provision of adequate computers on the basis of one student to one computer during class sessions, provision of adequate word processing laboratories fitted with air conditioners and good lighting by school authorities and provision of reprographic machines such as copiers and 
duplicators by school authorities. This study supports the study of Ejiofor and Osinem (2010), Egboka (2012) and Onojetah (2012) who have earlier identified similar strategies for enhancing the teaching of ICT such as adequate funding of ICT facilities, provision of adequate ICT facilities/equipment, provision of adequate electricity supply among others. The result of the hypotheses also revealed that there was no significant difference between male and female Business Education lecturers' mean rating of strategies for enhancing the teaching of ICT in Business Education programme, there was no significant difference between state and federal universities Business Education lecturers' mean rating of strategies for enhancing the teaching of ICT in Business Education programme.

\section{Conclusion}

Information and communication technology is an indispensable tool that could enhance effective teaching and learning in Business Education programme. Therefore, it is important that all lecturers and students should be acquainted with relevant skills and competencies that ICT provides to the recipient. Adequate funding to purchase ICT facilities should be embarked upon by school authorities.

\section{Recommendations}

The following recommendations are made by the study.

1) Business Education lecturers should undergo training and retraining in ICT programme to have more skills and competencies.

2) Adequate ICT facilities should be provided by university authorities to enable lecturers carry out their teaching of ICT effectively.

3) Constant electricity supply by university authorities to help generate power for computer equipment and gadgets.

4) Adequate qualified ICT staff should be employed by university authorities for enhancing the teaching of ICT in Business Education department.

5) University authorities should purchase modern ICT equipment for enhancing effective teaching of ICT.

6) ICT facilities should be maintained regularly by university authorities.

\section{References}

Aduwa-Ogiegbaen, E. S., \& Iyamu, S. O. (2005). Using ICT in secondary schools in Nigeria. Problems and prospects. Educational technology and Society. Retrieved April 28, 2005, from http://www.ifetsfnfo/journals8_13pdf

Bassey, U. C., Uwoven, G. U., Akuegwu, B. A., Udida, L. A., \& Ntukidem, E. P. (2007). Nigerian graduating students access to e-learning technology. Implications for higher education management. Business Education Journal, 6(2), 120-128.

Egboka, P. N. (2012). The status of information and communications technology (ICT) in empowering policy implementation in universities in south east zone of Nigeria. International Journal of Educational Research and Development, 8(2), 231-236.

Ejiofor, T. E., \& Osinem, C. E. (2010). Emerging roles of information and communication technology (ICT) in the implementation of agricultural teacher education programme in tertiary institution in Anambra and Enugu state of Nigeria. Journal of Vocational and Adult Education, 7(1), 14-24.

Esene, R. A. (2009). Research in education. Agbor: Royal Pace Publications.

Esene, R. A. (2012). Methods of teaching vocational business subjects. Agbor: Royal Pace Publications.

Ezenwafor, J. I. (2012). Adequacy of exposure to information and communication technology by graduating Business Education students of tertiary institution in Anambra State. Business Education Journal, 8(2), 45-60.

Federal Republic of Nigeria. (1998). National Policy on Education Abuja.

Federal Republic of Nigeria. (2004). National Policy on Education Abuja.

Igberaharha, O. C. (2009). Issues of information and communications technology (ICT). Assessment in teaching and learning of Business Education courses. Business Education Journal, VII (1), 95-105.

Inije, G. O. (2012). Strategies for upgrading the use of information and communication technology in business education. Association of Business Educators of Nigeria Book of Readings, 2(1), 163-167. 
Manir, A. K. (2009). Problems, challenges and benefits of implanting e-learning in Nigerian universities. International Journal of emerging technologies in learning, 4(1), 66-69.

National Planning Commission (2004). National Economic Empowerment and Development Strategies (NEEDS) Aubja.

Nwaiwu, B. N. (2009). The imperatives of information and communication technology (ICT) in business teacher education in the 21 century. Association of Business Educators of Nigeria. Book of Readings, 1(9), 97-103.

Ohakwe, S. N., \& Uba-Njoku. (2010). ICT access to education and quality standards Tripartite problems in polytechnic education. Business Education Journal, 7(2), 239-244.

Okigbo, E. C., \& Okeke, M. N. (2012). Challenges facing mathematics teachers in the utilization of ICT elements for mathematics instruction. International Journal of Educational Research and Development, 4(1), 70-76.

Okoli, B. E. (2010). A case for entrenchment of information and communication technology (ICT) literacy in the Business Education programme. Journal of Vocational and Adult Education, 7(1), 82-87.

Onojetah, S. O. (2012). Challenges of implementing Business Education program through information and communication technology (ICT). Association of Business Educators of Nigeria Book of Readings, 2(1), 156-161.

Ugwuanyi, M. O., \& Eze, M. E. (2009). Strategies for effective implementation of ICT driven curriculum for secretarial studies programme in nigerian polytechnics. Business Education Journal, 7(1), 62-80.

Ukor, L. O. (2009). Competencies needed to run a successful business enterprise. Delta Journal of Business Education, 1(4), 26-33.

Yomere, G. O., \& Esosa, B. O. (2011). Introduction to business policy and strategy. Warri: Xcel International Limited.

\section{Copyrights}

Copyright for this article is retained by the author(s), with first publication rights granted to the journal.

This is an open-access article distributed under the terms and conditions of the Creative Commons Attribution license (http://creativecommons.org/licenses/by/3.0/). 